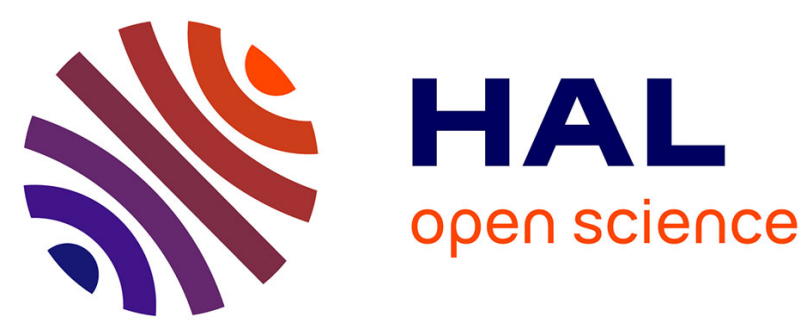

\title{
Triterpenes from Salvia argentea var. aurasiaca and their antibacterial and cytotoxic activities
}

\author{
Sara Bechkri, Abdulmagid Alabdul-Magid, Laurence \\ Voutquenne-Nazabadioko, Berrehal Djemaa, Ahmed Kabouche, Meryem \\ Lehbili, Hichem Lakhal, Amin Abedini, Sophie Gangloff, Hamid Morjani, et \\ al.
}

\section{To cite this version:}

Sara Bechkri, Abdulmagid Alabdul-Magid, Laurence Voutquenne-Nazabadioko, Berrehal Djemaa, Ahmed Kabouche, et al.. Triterpenes from Salvia argentea var. aurasiaca and their antibacterial and cytotoxic activities. Fitoterapia, 2019, pp.104296. 10.1016/j.fitote.2019.104296 . hal-02310372

\section{HAL Id: hal-02310372 \\ https://hal.univ-reims.fr/hal-02310372}

Submitted on 22 Sep 2021

HAL is a multi-disciplinary open access archive for the deposit and dissemination of scientific research documents, whether they are published or not. The documents may come from teaching and research institutions in France or abroad, or from public or private research centers.
L'archive ouverte pluridisciplinaire HAL, est destinée au dépôt et à la diffusion de documents scientifiques de niveau recherche, publiés ou non, émanant des établissements d'enseignement et de recherche français ou étrangers, des laboratoires publics ou privés. 
Triterpenes from Salvia argentea var. aurasiaca and their antibacterial and cytotoxic activities

Sara Bechkri ${ }^{\mathrm{a}, \mathrm{b}}$, Abdulmagid Alabdul Magid ${ }^{\mathrm{b}}$, Laurence Voutquenne-Nazabadioko $^{\mathrm{b}}$, Berrehal Djemaa $^{\mathrm{a}}$, Ahmed Kabouche ${ }^{\mathrm{a},{ }^{*}}$, Meryem Lehbilia, ${ }^{\mathrm{a},}$, Hichem Lakhal ${ }^{\mathrm{a}}$, Amin Abedini ${ }^{\mathrm{b}, \mathrm{c}}$, Sophie C. Gangloff $^{\mathrm{c}}$, Hamid Morjani ${ }^{\mathrm{d}}$, Zahia Kabouche ${ }^{\mathrm{a}^{*}}$.

${ }^{\text {a} U n i v e r s i t e ́ ~ d e s ~ f r e ̀ r e s ~ M e n t o u r i-C o n s t a n t i n e ~ 1, ~ D e ́ p a r t e m e n t ~ d e ~ c h i m i e, ~ L a b o r a t o i r e ~ d ' O b t e n t i o n ~ d e ~}$ Substances Thérapeutiques (LOST), Campus Chaabet-Ersas, 25000 Constantine, Algeria

bICMR-UMR CNRS 7312, Groupe Chimie des Substances Naturelles, Campus Sciences, Bât. 18, BP 1039, 51687 Reims Cedex 2, France

${ }^{c}$ EA 4691 «Biomatériaux et inflammation en site osseux», UFR de pharmacie, URCA, Reims, France

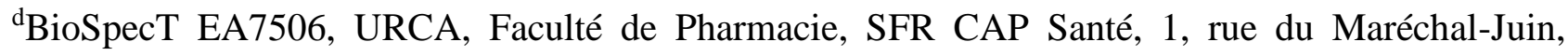
51096 Reims, France

* Corresponding author. Prof. Zahia Kabouche

E-mail address: zahiakabouche@gmail.com 


\section{Abstract}

Five undescribed ursane-type triterpenes, identified as 1 $\beta, 3 \beta, 15 \alpha$-trihydroxy-urs-9(11)-12-diene (1), $1 \beta, 3 \beta, 15 \alpha, 28$-tetrahydroxy-urs-9(11),12-diene (2), 1 $\beta, 3 \beta$-dihydroxy-urs-9(11),12-dien-28-al $1 \beta, 3 \beta, 7 \beta, 15 \alpha, 28$-pentahydroxy-urs-12-ene $\quad(4), \quad$ and $\quad 1 \beta, 3 \beta, 15 \alpha$-trihydroxy-urs-11-en-28-al together with five known compounds (6-10), were isolated from the acetone extract of the dried aerial parts of Salvia argentea L. var. aurasiaca (Pomel) Batt. et Trab. (Lamiaceae). Structures were elucidated on the basis of extensive spectroscopic analysis including HR-ESI-MS, 1D- and 2D-NMR techniques and comparison with literature data. The antibacterial evaluation of compounds 1-10 of the acetone extract of the dried aerial parts, in addition to nine compounds (1119) previously isolated from the exudate of the fresh aerial parts, by bioautography on Staphylococcus aureus followed by the determination of MIC values of active compounds by serial dilution technique against five bacteria, revealed that two compounds have an antibacterial effect comparable to antibiotics.

The cytotoxic activity evaluation of compounds 1-19 showed that Six compounds exhibited an antiproliferative activity against $\mathrm{K} 562$ and $\mathrm{HT} 1080$ cells with $\mathrm{IC}_{50}$ values ranging from 30.25 to $70.32 \mu \mathrm{M}$.

Keywords: Salvia argentea L. var. aurasiaca, Lamiaceae, ursane triterpenes. 


\section{Introduction}

The genus Salvia (family Lamiaceae), comprising about 900 species, widely distributed in various regions of the world, is represented by about 23 species in the Algerian flora, of which five are endemic [1]. Several investigations showed that Salvia species contain triterpenoids, diterpenoids, monoterpenes, and polyphenolics [2-12]. Salvia species possess biological properties e.g. antioxidant, antibacterial, anticancer, anti-inflammatory and cytotoxic activities [11-14]. Salvia argentea $\mathrm{L}$. is a plant species originating from the Mediterranean region [15]. and specifically in Algeria to treat respiratory diseases. The leaves are the most commonly used part, usually in the form of powder and exclusively administered orally [16]. Salvia argentea L. var. aurasiaca (Pomel) Batt. et Trab. is a plant species native from Algeria. In a previous paper, we described the isolation of eleven oleanane- and ursane-type triterpenes from the exudate of the fresh aerial parts of this plant (8, 9, and 11-19) (Figs. 1 and 2) [17]. In continuation of our research on the chemical constituents of $S$. argentea var. aurasiaca, we describe here the isolation and structural characterization of five new ursane-type triterpenes (1-5) along with five known compounds (6-10) from the acetone extract of its powdered dried aerial parts (Fig. 1). Their structures were elucidated by extensive spectroscopic methods including $1 \mathrm{D}-\left({ }^{1} \mathrm{H}\right.$ and $\left.{ }^{13} \mathrm{C}\right)$ and $2 \mathrm{D}-\mathrm{NMR}\left({ }^{1} \mathrm{H}-{ }^{1} \mathrm{H}-\mathrm{COSY}\right.$, HSQC, HMBC, and NOESY) experiments as well as HR-ESI-MS analysis. The antibacterial activity of compounds 1-19 was tested by bioautography on Staphylococcus aureus, followed by the determination of MIC values of active compounds against five bacteria (Enterococcus faecalis ATCC 1034, Staphylococcus aureus CIP 53.154, Escherichia coli CIP 54.127, Staphylococcus epidermidis, and Pseudomonas aeruginosa ATCC 9027). The antiproliferative activity of compounds 1-19 was evaluated against K562 and HT1080 cells.

\section{Results and discussion}

The acetone extract of the aerial parts of S. argentea var. aurasiaca was fractionated and purified by combination of chromatographic methods to provide five new ursane-type triterpenes (1-5) along 
with five known triterpenes (Fig. 1). The known compounds were identified as $1 \beta, 3 \beta$-dihydroxyurs-9(11)-12-diene (6) [18], 3 $\beta$-hydroxy-urs-9(11),12-diene (7) [19], 1 $\beta, 3 \beta, 15 \alpha, 28$-tetrahydroxyurs-12-ene (8) [17], 1 $\beta, 3 \beta, 11 \alpha, 15 \alpha$-tetrahydroxy-urs-12-ene (9) [17], and 3 $\beta$-hydroxy-olean9(11),12-diene (10) [20], by comparison of physical data with literature values and from spectroscopic evidence.
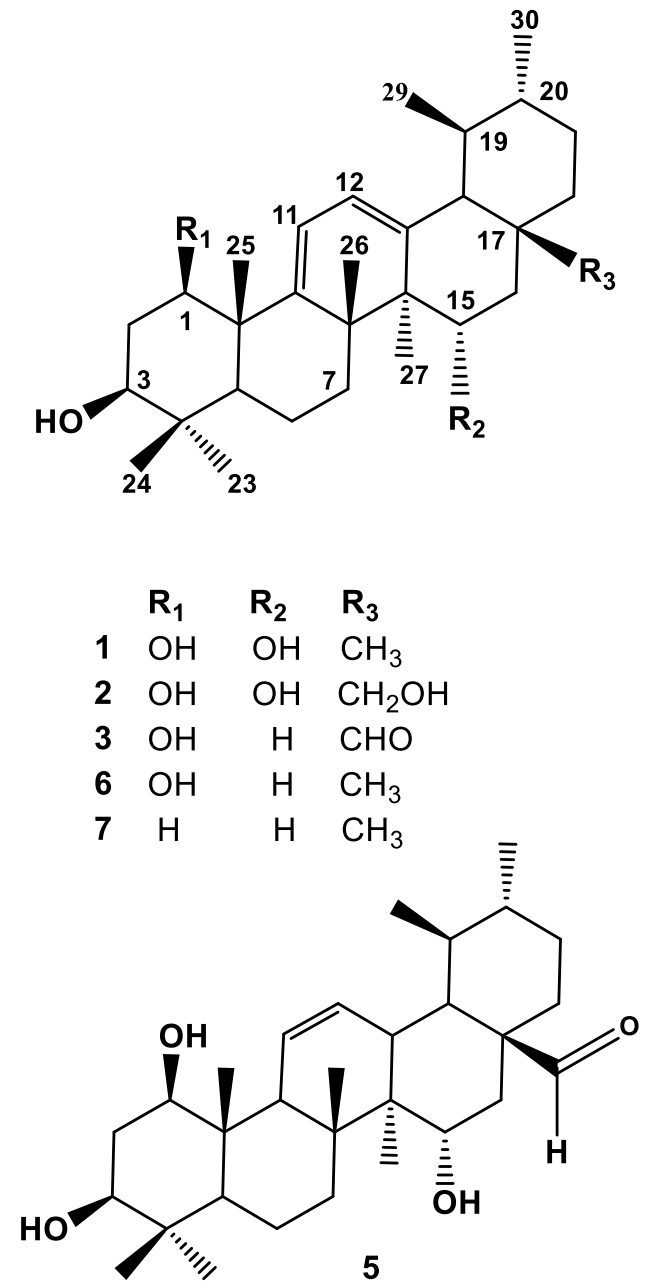
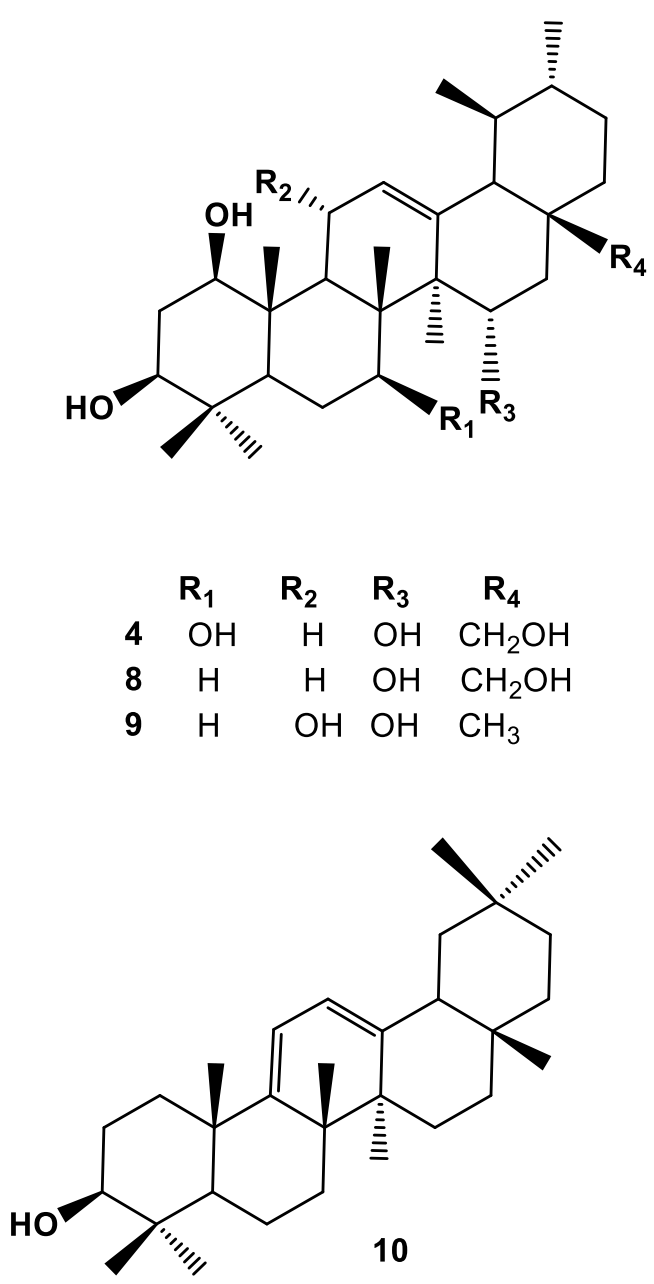

Fig. 1. Chemical structures of compounds 1-10 isolated from the acetone extract of dried aerial parts of $S$. argentea var. aurasiaca.

Compound 1 was obtained as white amorphous powder, it possessed the molecular formula $\mathrm{C}_{30} \mathrm{H}_{48} \mathrm{O}_{3}$ from its HR-ESI-MS at $m / z, 457.3688[\mathrm{M}+\mathrm{H}]^{+}$(calcd $\mathrm{C}_{30} \mathrm{H}_{49} \mathrm{O}_{3}, 457.3682$ ), indicating 7 degrees of unsaturation. The ${ }^{13} \mathrm{C}$ NMR spectrum of 1 showed 30 carbons due to eight methyls $\left(\delta_{\mathrm{C}}\right.$ 11.1, 15.1, 17.4, 19.2, 21.5, 23.0, 27.9, and 29.3), six $\mathrm{sp}^{3}$ methylene carbons, seven $\mathrm{sp}^{3}$ methine 
carbons (three oxygenated carbons at $\delta_{\mathrm{C}} 67.8,75.6$ and, 76.0), five $\mathrm{sp}^{3}$ quaternary carbons, and four olefinic carbons (two methine carbons at $\delta_{\mathrm{C}} 118.5$ and 124.6, and two quaternary carbons at $\delta_{\mathrm{C}}$ 141.7 and 153.2) (Table 1). The ${ }^{1} \mathrm{H}$ NMR spectrum of 1 (Table 1) displayed eight signals, corresponding to six tertiary methyls at $\delta_{\mathrm{H}} 0.82\left(\mathrm{~s}, \mathrm{CH}_{3}-24\right), 0.91\left(\mathrm{~s}, \mathrm{CH}_{3}-28\right), 0.98\left(\mathrm{~s}, \mathrm{CH}_{3}-27\right)$, $1.01\left(\mathrm{~s}, \mathrm{CH}_{3}-23\right), 1.25\left(\mathrm{~s}, \mathrm{CH}_{3}-26\right)$, and $1.28\left(\mathrm{~s}, \mathrm{CH}_{3}-25\right)$, and two secondary methyls at $\delta_{\mathrm{H}} 0.85$ (d, $J=4.1 \mathrm{~Hz},\left(\mathrm{~s}, \mathrm{CH}_{3}-29\right)$ and 0.94 (brs, $\left.\mathrm{CH}_{3}-30\right)$, three oxymethines signals at $\delta_{\mathrm{H}} 3.34(\mathrm{dd}, J=12.5$ and 4.1 Hz, H-3), 3.86 (dd, J=11.5 and 4.5 Hz, H-1), and 4.35 (dd, $J=11.5$ and $6.0 \mathrm{~Hz}, \mathrm{H}-15$ ), and two doublets $(J=6.1 \mathrm{~Hz})$ assigned to the olefinic protons $\mathrm{H}-11\left(\delta_{\mathrm{H}} 6.69\right)$ and $\mathrm{H}-12\left(\delta_{\mathrm{H}} 5.55\right)$ of $\Delta^{9(11)-12}$ ursane skeleton $[18,21]$. The location of two trisubstituted double bonds was confirmed by the HMBC experiment. From HMBC spectrum, H-11 showed correlation with $\delta_{C} 44.4$ (C-8), 153.2 (C9), 124.6 (C-12), and 141.7 (C-13), whereas H-12 correlated with $\delta_{\mathrm{C}} 118.5(\mathrm{C}-11), \mathrm{C}-13$ (141.7), 46.7 (C-14), 57.5 (C-18). By detailed analysis of the NMR spectroscopic data (HSQC, COSY, HMBC and NOESY) and comparison of the ${ }^{1} \mathrm{H}$ and ${ }^{13} \mathrm{C}$ NMR spectra of $\mathbf{1}$ with $1 \beta, 3 \beta$-dihydroxyurs-9(11)-12-diene (6), no difference between the two compounds was evident except for the presence of an oxymethine signal instead of those of the methylene signal $\left(\mathrm{H}_{2}-15\right)$ in $\mathbf{6}$. The oxymethine carbon signal was assigned to the $\mathrm{C}-15$ position $\left(\delta_{\mathrm{C}} 67.8\right)$ due to the observed HMBC correlations of $\mathrm{H}-15$ with the methyl C-27 and to the carbons C-8, C-13, C-14, C-16 $\left(\delta_{\mathrm{C}} 39.5\right)$, and $\mathrm{C}-17\left(\delta_{\mathrm{C}} 34.9\right)$. The position of the oxygenated methine at C-15 was also confirmed by the presence of correlations in COSY spectrum between $\delta_{\mathrm{H}} 1.30$ and $1.94(\mathrm{H}-16)$ and $\delta_{\mathrm{H}} 4.35(\mathrm{H}-15)$. The coupling constants of H-1 $(11.5,4.5 \mathrm{~Hz})$ and $\mathrm{H}-3(12.5,4.1 \mathrm{~Hz})$ indicated their $\alpha$-axial orientations. This was confirmed by the NOE correlations observed between $\mathrm{H}-3 \alpha / \mathrm{H}-5 \alpha$ and $\mathrm{H}-23 \alpha$ and between $\mathrm{H}-1 \alpha / \mathrm{H}-9 \alpha[17]$. The hydroxyl group at $\mathrm{C}-15$ was shown to be $\alpha$-oriented by the coupling constants of H-15 $\beta$-axial $\left(J_{\mathrm{H}-15 \beta \text {-ax-H-16 } \alpha \text {-ax }}=11.5 \mathrm{~Hz}\right)$ and by the NOE correlations between $\mathrm{H}-15 \beta / \mathrm{H}-26 \beta$ and $\mathrm{H}-15 \beta / \mathrm{H}-18 \beta$. The full assignments of the ${ }^{1} \mathrm{H}$ NMR and ${ }^{13} \mathrm{C}$ NMR data of $\mathbf{1}$ are listed in Table 1. On 
the basis of the above evidence, the structure of compound $\mathbf{1}$ was established as $1 \beta, 3 \beta, 15 \alpha$ trihydroxy-urs-9(11)-12-diene.

Compound 2 was obtained as white amorphous powder. Its molecular formula was determined as $\mathrm{C}_{30} \mathrm{H}_{48} \mathrm{O}_{4}$ by the HR-ESI-MS at $m / z 495.3457[\mathrm{M}+\mathrm{Na}]^{+}$(calc for $\mathrm{C}_{30} \mathrm{H}_{48} \mathrm{O}_{4} \mathrm{Na}, 495.3450$ ). The ${ }^{1} \mathrm{H}$ and ${ }^{13} \mathrm{C}$ spectra of $\mathbf{2}$ (Table 1) closely resembled to compound $\mathbf{1}$, indicating that it was also ursane9(11)-12-diene triterpene. The difference was the replacement of $\mathrm{CH}_{3}-28$ by a hydroxymethylene group (Table 1). The attachment of the hydroxymethylene group to C-17 was readily confirmed by the HMBC correlations from $\mathrm{H}_{2}-28$ to $\mathrm{C}-22, \mathrm{C}-18$, and $\mathrm{C}-16$. As expected, a NOE interaction was observed between H-28 and H-18. Thus compound 2 was identified as $1 \beta, 3 \beta, 15 \alpha, 28$-tetrahydroxyurs-9(11),12-diene.

Compound 3 was obtained as white amorphous powder with the molecular formula, $\mathrm{C}_{30} \mathrm{H}_{47} \mathrm{O}_{3}$, determined by the positive ion HR-ESI-MS at $m / z, 477.3349[\mathrm{M}+\mathrm{Na}]^{+}$(calcd for $\mathrm{C}_{30} \mathrm{H}_{46} \mathrm{O}_{3} \mathrm{Na}$, 477.3345). Its ${ }^{1} \mathrm{H}$ and ${ }^{13} \mathrm{C}$ NMR data differed from those of compound $\mathbf{1}$ only in rings $\mathrm{D}$ and $\mathrm{E}$ (Table 1$) . \mathrm{CH}_{3}-28$ was replaced by a formyl $\left(\delta_{\mathrm{C}} 207.4 / \delta_{\mathrm{H}} 9.34\right.$, s). This was confirmed by HMBC correlations from $\mathrm{H}-18, \mathrm{H}-16$ and $\mathrm{H}-22$ to $\mathrm{C}-28$. A NOE interaction between the aldehyde proton and $\mathrm{H}-18\left(\delta_{\mathrm{C}} 2.15\right)$ indicated the expected $\beta$ orientation of the aldehyde function. The shielding of C-14 $\left(\delta_{\mathrm{C}} 42.9\right)$ and C-16 $\left(\delta_{\mathrm{C}} 23.9\right)$ and the deshielding of C-27 $\left(\delta_{\mathrm{C}} 18.3\right)$ indicated the absence of hydroxyl at C-15. This was confirmed by the chemical shifts of $\mathrm{C}-15\left(\delta_{\mathrm{C}} 26.3\right)$ and $\mathrm{H}_{2}-15\left(\delta_{\mathrm{H}} 1.16\right.$ and 1.94). $\mathrm{CH}_{3}-27$ showed a correlation with $\mathrm{C}-15$ in the $\mathrm{HMBC}$ spectrum. Therefore, the structure of compound $\mathbf{3}$ was identified as 1 $\beta, 3 \beta$-dihydroxy-urs-9(11),12-dien-28-al.

Compound 4 was obtained as white amorphous powder with the molecular formula $\mathrm{C}_{30} \mathrm{H}_{50} \mathrm{O}_{5}$ (HRESI-MS $m / z$ 513.3564 [M+Na] $]^{+}$, calcd $\left.\mathrm{C}_{30} \mathrm{H}_{50} \mathrm{O}_{5} \mathrm{Na}, 513.3556\right)$. By detailed analysis of the 1D- and 2D-NMR spectroscopic data and comparison of the ${ }^{1} \mathrm{H}$ and ${ }^{13} \mathrm{C}$ NMR spectra of 4 (Table 1) with 
$1 \beta, 3 \beta, 15 \alpha, 28$-tetrahydroxy-urs-12-ene (8) [17], no difference between the two compounds was evident except for the presence of an oxymethine signal instead of those of the methylene signal $\left(\mathrm{H}_{2}-7\right)$ in 8 . The oxymethine was assigned to the $\mathrm{C}-7$ position $\left(\delta_{\mathrm{C}} 71.5\right)$ due to the observed HMBC correlations of $\mathrm{H}-7\left(\delta_{\mathrm{H}} 3.85\right.$, dd, $J=11.3$ and $\left.4.8 \mathrm{~Hz}\right)$ to the $\mathrm{CH}_{3}-26\left(\delta_{\mathrm{C}} 9.2\right), \mathrm{C}-6\left(\delta_{\mathrm{C}} 26.6\right), \mathrm{C}-9\left(\delta_{\mathrm{C}}\right.$ 49.2), and C-5 ( $\left.\delta_{\mathrm{C}} 49.7\right)$. The COSY correlations observed between $\mathrm{H}_{2}-6\left(\delta_{\mathrm{H}} 1.69,1.77\right) / \mathrm{H}-7$ and $\mathrm{H}_{2-}$ 6/H-5 $\left(\delta_{\mathrm{H}} 0.78\right)$ confirmed the position of the extra secondary hydroxyl group at C-7. The multiplicity and coupling constant of $\mathrm{H}-7$ proposed the hydroxyl group to be in the less hindered equatorial orientation ( $\beta$ oriented) as deduced by the axial-axial and axial-equatorial couplings of $\mathrm{H}$ 7 with H-6 protons $\left(J_{\mathrm{H}-6 \mathrm{ax}-\mathrm{H}-7 \mathrm{ax}}=11.3 \mathrm{~Hz}\right)$. Thus, compound 4 was deduced to be $1 \beta, 3 \beta, 7 \beta, 15 \alpha, 28$ pentahydroxy-urs-12-ene.

The molecular formula of compound 5 was established as $\mathrm{C}_{30} \mathrm{H}_{48} \mathrm{O}_{4}$ (HR-ESI-MS $\mathrm{m} / \mathrm{z} 495.3445$ $[\mathrm{M}+\mathrm{Na}]^{+}$, calcd 495.3450). Comparison of the 1D- and 2D-NMR spectroscopic data of compound 5 (Table 1) with those of compounds $\mathbf{1}$ and $\mathbf{3}$ showed similarities with the exception of the signals associated with olefinic protons and carbons. Based on these similarities, compound $\mathbf{5}$ should be a $1 \beta, 3 \beta, 15 \alpha$-trihydroxy-ursane-28-al derivative. The ${ }^{1} \mathrm{H}-\mathrm{NMR}$ spectrum showed two olefinic proton signals at $\delta_{\mathrm{H}} 5.57(\mathrm{H}-11)$ and $6.61(\mathrm{H}-12)($ each $1 \mathrm{H}, \mathrm{dt}, J=10.1$ and $1.8 \mathrm{~Hz})$, correlated in the HSQC spectrum with two methine carbons at $\delta_{\mathrm{C}} 131.6$ and 127.8 , respectively. $\mathrm{H}-11$ correlated in the ${ }^{1} \mathrm{H}$ ${ }^{1} \mathrm{H}-\mathrm{COSY}$ spectrum with $\mathrm{H}-12$ and with the signal at $\delta_{\mathrm{H}} 2.09$ (brs, H-9), whereas H-12 correlated in the same spectrum, in addition to $\mathrm{H}-11$, with the signal at $\delta_{\mathrm{H}} 1.88$ (dd, $J=10.5$ and $1.8 \mathrm{~Hz}, \mathrm{H}-13$ ). The location of the double bond $\left(\Delta^{11-12}\right)$ was confirmed by the HMBC correlations observed between H-11/C-8 ( $\left.\delta_{C} 42.6\right), \mathrm{H}-11 / \mathrm{C}-10\left(\delta_{\mathrm{C}} 42.1\right), \mathrm{H}-12 / \mathrm{C}-13\left(\delta_{\mathrm{C}} 44.2\right), \mathrm{H}-12 / \mathrm{C}-14\left(\delta_{\mathrm{C}} 45.3\right)$, and $\mathrm{H}-12 / \mathrm{C}-18\left(\delta_{\mathrm{C}} 46.4\right)$. Thus, compound 5 was elucidated as $1 \beta, 3 \beta, 15 \alpha$-trihydroxy-urs-11-en-28-al. 
Table 1

NMR spectroscopic data of compounds 1-3 in $\mathrm{CDCl}_{3}$ and 4-5 in $\mathrm{CD}_{3} \mathrm{OD}{ }^{\mathrm{a}}$

\begin{tabular}{|c|c|c|c|c|c|c|c|c|c|c|}
\hline \multirow[t]{2}{*}{ No. } & \multicolumn{2}{|l|}{1} & \multicolumn{2}{|l|}{2} & \multicolumn{2}{|l|}{3} & \multicolumn{2}{|l|}{4} & \multicolumn{2}{|l|}{5} \\
\hline & $\delta_{\mathrm{H}} \mathrm{m}(J$ in $\mathrm{Hz})$ & $\delta_{\mathrm{C}}$ & $\delta_{\mathrm{H}} \mathrm{m}(J$ in $\mathrm{Hz})$ & $\delta_{\mathrm{C}}$ & $\delta_{\mathrm{H}} \mathrm{m}(\mathrm{J}$ in $\mathrm{Hz})$ & $\delta_{\mathrm{C}}$ & $\delta_{\mathrm{H}} \mathrm{m}(\mathrm{J}$ in $\mathrm{Hz})$ & $\delta_{\mathrm{C}}$ & $\delta_{\mathrm{H}} \mathrm{m}(\mathrm{J}$ in $\mathrm{Hz})$ & $\delta_{\mathrm{C}}$ \\
\hline 1 & $3.86 \mathrm{dd}(11.5,4.5)$ & 76.0 & $3.87 \mathrm{dd}(11.5,4.5)$ & 76.3 & $3.78 \mathrm{dd}(11.6,4.5)$ & 75.9 & $3.35 \mathrm{dd}(11.5,4.5)$ & 79.0 & 3.44 dd $(11.4,3.3)$ & 79.4 \\
\hline 2 & $\begin{array}{l}1.75 \\
1.95\end{array}$ & 38.7 & $\begin{array}{l}1.75 \\
1.97 \mathrm{dt}(12.4,4.4)\end{array}$ & 38.5 & $\begin{array}{l}1.74 \\
1.97\end{array}$ & 38.1 & $\begin{array}{l}1.76 \\
1.77\end{array}$ & 37.1 & $\begin{array}{l}1.79 \\
1.80\end{array}$ & 37.1 \\
\hline 3 & $3.34 \mathrm{dd}(12.5,4.1)$ & 75.6 & $3.35 \mathrm{dd}(12.1,4.3)$ & 75.5 & $3.35 \mathrm{dd}(12.1,4.2)$ & 75.7 & $3.24 \mathrm{dd}(12.0,4.1)$ & 75.1 & $3.20 \mathrm{dd}(12.0,4.6)$ & 75.3 \\
\hline 4 & & 38.7 & - & 39.0 & & 39.1 & & 37.9 & & 38.5 \\
\hline 5 & 0.78 & 49.1 & 0.79 & 49.0 & 0.78 & 48.8 & $0.78 \mathrm{~d}(11.9)$ & 49.7 & 0.60 brd (11.8) & 51.9 \\
\hline 6 & $\begin{array}{l}1.63 \\
1.70\end{array}$ & 18.4 & $\begin{array}{l}1.65 \\
1.70\end{array}$ & 18.2 & $\begin{array}{l}1.63 \\
1.68\end{array}$ & 18.2 & $\begin{array}{l}1.69 \\
1.77\end{array}$ & 26.6 & $\begin{array}{l}1.58 \\
1.64\end{array}$ & 17.6 \\
\hline 7 & $\begin{array}{l}1.53 \\
2.05 \mathrm{dt}(12.6,5.6)\end{array}$ & 34.3 & $\begin{array}{l}1.51 \\
2.07 \operatorname{td}(12.1,5.3)\end{array}$ & 34.2 & $\begin{array}{l}1.36 \\
1.68\end{array}$ & 31.0 & $3.85 \mathrm{dd}(11.3,4.8)$ & 71.5 & $\begin{array}{l}1.52 \\
2.35\end{array}$ & 33.7 \\
\hline 8 & & 44.4 & & 44.0 & & 40.9 & & 46.9 & & 42.6 \\
\hline 9 & & 153.2 & & 153.4 & & 153.5 & 1.65 & 49.2 & $2.09 \mathrm{brs}$ & 53.0 \\
\hline 10 & & 44.9 & & 45.0 & & 44.9 & & 43.2 & & 42.1 \\
\hline 11 & $6.69 \mathrm{~d}(6.1)$ & 118.5 & $6.70 \mathrm{~d}(6.2)$ & 118.5 & $6.58 \mathrm{~d}(6.0)$ & 117.4 & $\begin{array}{l}2.18 \mathrm{ddd}(17.2,11.7,2.2) \\
2.79 \mathrm{dt}(17.2,5.3)\end{array}$ & 26.2 & $5.57 \mathrm{dt}(10.1,1.8)$ & 131.6 \\
\hline 12 & $5.55 \mathrm{~d}(6.1)$ & 124.6 & $5.55 \mathrm{~d}(6.2)$ & 124.9 & $5.63 \mathrm{~d}(6.0)$ & 124.4 & $5.34 \mathrm{dd}(5.3,2.2)$ & 128.2 & $6.61 \mathrm{dt}(10.8,1.8)$ & 127.8 \\
\hline 13 & & 141.7 & & 140.6 & & 140.6 & & 137.8 & $1.88 \mathrm{dd}(10.5,1.8)$ & 44.2 \\
\hline 14 & & 46.7 & & 47.0 & & 42.9 & & 48.8 & & 45.3 \\
\hline 15 & $4.35 \mathrm{dd}(11.5,6.0)$ & 67.8 & $4.35 \mathrm{dd}(11.6,5.9)$ & 66.8 & $\begin{array}{l}1.16 \\
1.94 \mathrm{~m}\end{array}$ & 26.3 & $4.19 \mathrm{dd}(11.8,5.3)$ & 65.6 & $4.0 \mathrm{dd}(10.5,5.8)$ & 66.2 \\
\hline 16 & $\begin{array}{l}1.30 \\
1.94 \text { brt (11.5) }\end{array}$ & 39.5 & $\begin{array}{l}1.59 \mathrm{~m} \\
1.90 \mathrm{brt}(12.8)\end{array}$ & 34.7 & $\begin{array}{l}1.74 \\
2.05 \operatorname{td}(11.5,3.5)\end{array}$ & 23.9 & $\begin{array}{l}1.50 \mathrm{dd}(13.1,3.9) \\
1.93 \mathrm{t}(13.1)\end{array}$ & 31.8 & $\begin{array}{l}1.83 \\
1.88\end{array}$ & 32.5 \\
\hline 17 & & 34.9 & & 39.0 & - & 49.9 & & 38.3 & & 52.2 \\
\hline 18 & $1.49 \mathrm{~d}(10.8)$ & 57.5 & $1.56 \mathrm{~m}$ & 52.5 & $2.15 \mathrm{~d}(11.2)$ & 50.7 & $1.42 \mathrm{~d}(11.1)$ & 55.2 & $1.70 \mathrm{dd}(11.8,2.7)$ & 46.4 \\
\hline 19 & $1.31 \mathrm{~m}$ & 38.9 & $1.41 \mathrm{~m}$ & 38.5 & $1.40 \mathrm{~m}$ & 38.1 & 1.45 & 39.3 & 1.63 & 38.9 \\
\hline 20 & $0.94 \mathrm{~m}$ & 39.1 & $0.97 \mathrm{~m}$ & 39.0 & $1.05 \mathrm{~m}$ & 38.8 & $0.90 \mathrm{~m}$ & 39.2 & $1.00 \mathrm{~m}$ & 39.2 \\
\hline 21 & $\begin{array}{l}1.28 \mathrm{~m} \\
1.43 \mathrm{~m}\end{array}$ & 31.0 & $\begin{array}{l}1.30 \mathrm{~m} \\
1.52\end{array}$ & 30.3 & $\begin{array}{l}1.30 \mathrm{~m} \\
1.60 \mathrm{~m}\end{array}$ & 30.1 & $\begin{array}{l}1.29 \mathrm{~m} \\
1.49 \mathrm{dd}(13.1,3.9)\end{array}$ & 30.3 & $\begin{array}{l}1.32 \mathrm{~m} \\
1.58 \mathrm{~m}\end{array}$ & 29.5 \\
\hline 22 & $\begin{array}{l}1.29 \mathrm{~m} \\
1.51 \mathrm{~m}\end{array}$ & 40.9 & $\begin{array}{l}1.52 \\
1.67 \mathrm{~m}\end{array}$ & 34.8 & $\begin{array}{l}1.28 \mathrm{~m} \\
1.42 \mathrm{~m}\end{array}$ & 31.7 & $\begin{array}{l}1.39 \mathrm{td}(13.1,3.8) \\
1.63 \mathrm{dt}(13.1,2.9)\end{array}$ & 34.6 & $\begin{array}{l}1.12 \mathrm{~m} \\
1.55 \mathrm{~m}\end{array}$ & 31.2 \\
\hline 23 & $1.01 \mathrm{~s}$ & 27.9 & $1.02 \mathrm{~s}$ & 27.9 & $1.00 \mathrm{~s}$ & 27.8 & $1.01 \mathrm{~s}$ & 27.2 & $0.95 \mathrm{~s}$ & 26.9 \\
\hline 24 & $0.82 \mathrm{~s}$ & 15.1 & $0.83 \mathrm{~s}$ & 15.2 & $0.82 \mathrm{~s}$ & 15.1 & $0.81 \mathrm{~s}$ & 14.8 & $0.76 \mathrm{~s}$ & 14.1 \\
\hline 25 & $1.28 \mathrm{~s}$ & 19.2 & $1.29 \mathrm{~s}$ & 19.2 & $1.25 \mathrm{~s}$ & 18.5 & $1.05 \mathrm{~s}$ & 10.6 & $0.94 \mathrm{~s}$ & 12.4 \\
\hline 26 & $1.25 \mathrm{~s}$ & 23.0 & $1.24 \mathrm{~s}$ & 22.9 & $0.94 \mathrm{~s}$ & 22.0 & $1.09 \mathrm{~s}$ & 9.2 & $0.83 \mathrm{~s}$ & 16.0 \\
\hline 27 & $0.98 \mathrm{~s}$ & 11.1 & $1.01 \mathrm{~s}$ & 11.1 & $0.95 \mathrm{~s}$ & 18.3 & $1.18 \mathrm{~s}$ & 15.7 & $1.04 \mathrm{~s}$ & 11.2 \\
\hline 28 & $0.91 \mathrm{~s}$ & 29.3 & $\begin{array}{l}3.30 \mathrm{~d}(11.1) \\
3.57 \mathrm{~d}(11.1)\end{array}$ & 70.5 & $9.34 \mathrm{~s}$ & 207.4 & $\begin{array}{l}3.11 \mathrm{~d}(11.1) \\
3.50 \mathrm{~d}(11.1)\end{array}$ & 69.2 & $9.25 \mathrm{~s}$ & 206.1 \\
\hline 29 & $0.85 \mathrm{~d}(6.4)$ & 17.4 & $0.88 \mathrm{~d}(6.5)$ & 17.2 & $0.92 \mathrm{~d}(6.4)$ & 16.6 & $0.88 \mathrm{~d}(6.1)$ & 16.5 & $1.12 \mathrm{~d}(6.2)$ & 17.8 \\
\hline 30 & 0.94 brs & 21.5 & $0.97 \mathrm{~s}$ & 21.4 & $01.00 \mathrm{~s}$ & 21.2 & $0.96 \mathrm{~d}(6.3)$ & 20.2 & $0.97 \mathrm{~s}$ & 19.4 \\
\hline
\end{tabular}

${ }^{\text {a }}$ Overlapped protons are reported without designated multiplicity.

In order to screen the antibacterial potential of compounds isolated from the acetone extract of the dried aerial parts (1-10), in addition to compounds previously isolated from the exudate of the fresh aerial parts (11-19) [17], a bioautography assay was applied on a sensitive strain of Staphylococcus aureus CIP 53.154. S. aureus is a Gram-positive cocci bacterium frequently found on the skin and in the respiratory tract, and can be responsible for nosocomial infections. Compounds $\mathbf{4 ,} \mathbf{8}$, and $\mathbf{1 7 -}$ 19 were the only active compounds as revealed by the white inhibition zones observed on the TLC plate around the compound spots. 


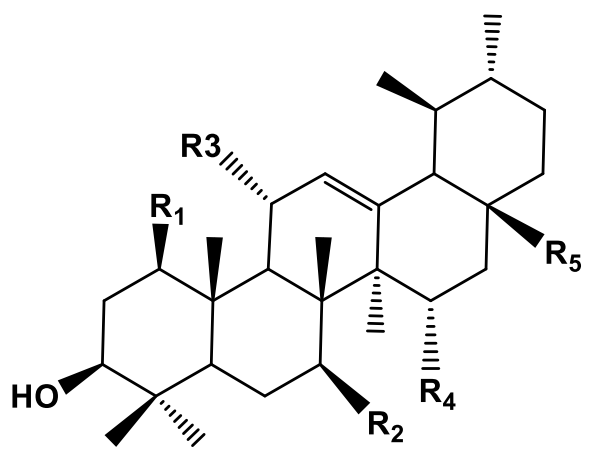

$\begin{array}{llllll} & \mathbf{R}_{\mathbf{1}} & \mathbf{R}_{\mathbf{2}} & \mathbf{R}_{\mathbf{3}} & \mathbf{R}_{\mathbf{4}} & \mathbf{R}_{\mathbf{5}} \\ \mathbf{8} & \mathrm{OH} & \mathrm{H} & \mathrm{H} & \mathrm{OH} & \mathrm{CH}_{2} \mathrm{OH} \\ \mathbf{9} & \mathrm{OH} & \mathrm{H} & \mathrm{OH} & \mathrm{OH} & \mathrm{CH}_{3} \\ \mathbf{1 1} & \mathrm{OH} & \mathrm{H} & \mathrm{OCH}_{3} & \mathrm{OH} & \mathrm{CH}_{3} \\ \mathbf{1 2} & \mathrm{OH} & \mathrm{H} & \mathrm{OH} & \mathrm{H} & \mathrm{CH}_{3} \\ 13 & \mathrm{OH} & \mathrm{H} & \mathrm{OCH}_{3} & \mathrm{H} & \mathrm{CH}_{3} \\ 14 & \mathrm{OH} & \mathrm{H} & \mathrm{OCH}_{3} & \mathrm{OH} & \mathrm{CHO} \\ 15 & \mathrm{OH} & \mathrm{H} & \mathrm{H} & \mathrm{OH} & \mathrm{CHO} \\ 16 & \mathrm{OH} & \mathrm{H} & \mathrm{OCH}_{3} & \mathrm{H} & \mathrm{CH}_{2} \mathrm{OH} \\ 18 & \mathrm{H} & \mathrm{OH} & \mathrm{H} & \mathrm{OH} & \mathrm{CH}_{2} \mathrm{OH}\end{array}$
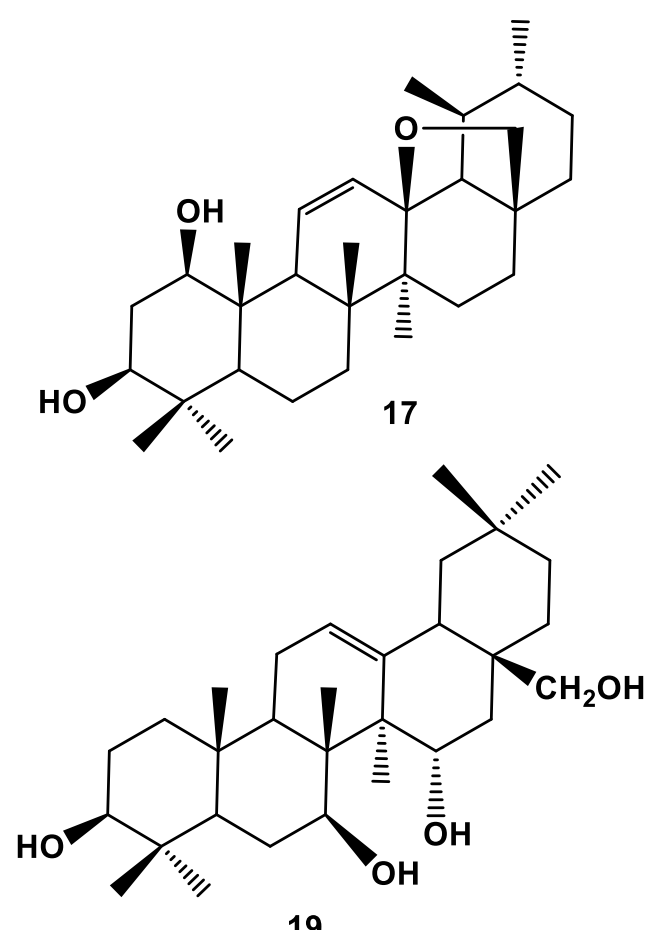

19

Fig. 2. Chemical structures of compounds 8, 9, and 11-19 isolated from the exudate of the fresh aerial parts of $S$. argentea var. aurasiaca

A serial liquid dilution technique in 96-well microtiter plates was used to determine the minimum inhibitory concentration (MIC) of these five compounds against the five bacteria, Enterococcus faecalis ATCC 1034, Staphylococcus aureus CIP 53.154, Escherichia coli CIP 54.127, Staphylococcus epidermidis, and Pseudomonas aeruginosa ATCC 9027 (Table 2). Compound 19 was the most active one with MIC values similar to gentamicin and vancomycin, used as standards (Table 2). Compound 19 showed potent inhibitory effect against S. epidermidis (MIC $3.9 \mu \mathrm{g} / \mathrm{mL}$ ) and against E. coli and P. aeruginosa (MIC $7.8 \mu \mathrm{g} / \mathrm{mL}$ ). The results showed also a good inhibitory effect of compounds 4 and 18 against $S$. aureus, S. epidermidis, and E. coli (MIC $62.5 \mu \mathrm{g} / \mathrm{mL}$ ). Compounds $\mathbf{8}$ and $\mathbf{1 7}$ showed a moderate to low inhibitory effect against the five tested bacteria with MIC values ranging from 125 to $500 \mu \mathrm{g} / \mathrm{mL}$ (Table 2). 
Table 2

Minimum inhibitory concentration (MIC) values of compounds isolated from S. argentea var aurasiaca in liquid medium. $^{\mathrm{a}}$

\begin{tabular}{lccccc}
\hline \multirow{2}{*}{ Compounds } & $\begin{array}{c}\text { E. faecalis } \\
\text { (ATCC 1034) }\end{array}$ & $\begin{array}{c}\text { S. aureus } \\
\text { (CIP53.154) }\end{array}$ & $\begin{array}{c}\text { E. coli } \\
\text { (CIP 54.127) }\end{array}$ & S. epidermidis & $\begin{array}{c}\text { P. aeruginosa } \\
\text { (ATCC9027) }\end{array}$ \\
\hline 4 & 125 & 62.5 & 62.5 & 62.5 & 62.5 \\
8 & 125 & 125 & 125 & 125 & 125 \\
17 & 500 & 500 & $>500$ & $>500$ & $>500$ \\
18 & 125 & 62.5 & 62.5 & 62.5 & 125 \\
19 & 125 & 62.5 & 7.8 & 3.9 & 7.8 \\
Gentamicin * & 16 & 4 & 4 & 0.25 & 8 \\
Vancomycin & $>64$ & $>64$ & 16 & 4 & $>64$ \\
\hline a No bacterial growth inhibition observed in bioautography assay for compounds 1-3, 5-7, and 9-16. \\
*used as standard.
\end{tabular}

The cytotoxic activity of compounds 1-19 was evaluated against chronic myeloid leukemia K562 and fibrosarcoma HT1080 cells. Only compounds 2, 3, 5, 8, 9, and 11 exhibited a moderate antiproliferative activity with $\mathrm{IC}_{50}$ ranging from 30.25 to $70.32 \mu \mathrm{M}$ (Table 3 ).

Table 3

Cytotoxic activity of compounds 1-19 against HT1080 and K562 cells.

\begin{tabular}{lll}
\hline Compounds $^{\mathrm{a}}$ & \multicolumn{2}{c}{$\mathrm{IC}_{50}(\mu \mathrm{M})^{\mathrm{b}}$} \\
\cline { 2 - 3 } & $\mathrm{HT} 1080$ & $\mathrm{~K} 562$ \\
\hline 2 & $30.25 \pm 0.41$ & $>100(26.5 \pm 3.98)^{\mathrm{c}}$ \\
3 & $35.15 \pm 0.19$ & $66.81 \pm 0.18$ \\
5 & $40.18 \pm 0.19$ & $49.15 \pm 0.19$ \\
8 & $>100(36.8 \pm 2.76)^{\mathrm{c}}$ & $70.32 \pm 0.19$ \\
9 & $31.12 \pm 0.51$ & $50.03 \pm 0.18$ \\
11 & $32.14 \pm 0.62$ & $54.3 \pm 0.18$ \\
Doxorubicin* $^{2}$ & $0.59 \pm 0.05$ & $0.59 \pm 0.04$ \\
\hline
\end{tabular}

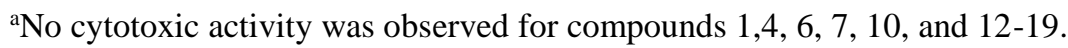

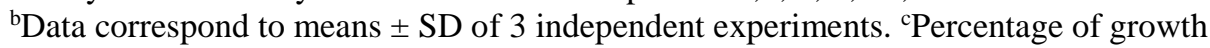
inhibition at a concentration of $100 \mu \mathrm{M}$.

*used as standard.

In conclusion, the present work reported five new ursane-type triterpenes (1-5) along with four known ursane-type triterpenes (6-9), and one oleanane-type triterpene (10) from the acetone extract of the dried aerial parts of Salvia argentea L. var. aurasiaca (Pomel) Batt. et Trab. (Lamiaceae) collected from Ain El-Bey in Constantine Province (North-Eastern Algerian). Compounds 8 and 9 were previously obtained from the exudate of the fresh aerial parts of this plant while compounds 7 and 10 were previously isolated from Salvia species. Compound $\mathbf{6}$ was isolated for the first time from Salvia species and family Lamiaceae.

Compounds (1-10) isolated from the acetone extract of the dried aerial parts and compounds previously isolated from the exudate of the fresh aerial parts (11-19) [17], were tested for their 
antibacterial and cytotoxic activities. Five compounds showed antibacterial activity against $E$. faecalis, S. aureus, E. coli, S. epidermidis, and P. aeruginosa. Compound 19 showed potent inhibitory effect with MIC values similar to gentamicin and vancomycin, used as standards, against S. epidermidis (MIC $3.9 \mu \mathrm{g} / \mathrm{mL}$ ) and against E. coli and P. aeruginosa (MIC $7.8 \mu \mathrm{g} / \mathrm{mL}$ ).

Six compounds exhibited antiproliferative activity against K562 and HT1080 cells with IC $_{50}$ ranging from 30.25 to $70.32 \mu \mathrm{M}$.

\section{Experimental}

\subsection{General experimental procedures}

Optical rotations were measured in $\mathrm{MeOH}$ or $\mathrm{CHCl}_{3}$ using a Perkin-Elmer 341 Polarimeter. ${ }^{1} \mathrm{H}-$, ${ }^{13} \mathrm{C}$-NMR and 2D-NMR measurements were recorded in $\mathrm{CD}_{3} \mathrm{OD}$ or $\mathrm{CDCl}_{3}$ on a Bruker Avance III 500 spectrometer $\left({ }^{1} \mathrm{H} \mathrm{NMR}\right.$ at $500 \mathrm{MHz}$ and ${ }^{13} \mathrm{C} \mathrm{NMR}$ at $\left.125 \mathrm{MHz}\right)$ equipped with a $5 \mathrm{~mm}$ TCI cryoprobe. 2D-NMR experiments were performed using standard Bruker microprograms (TopSpin 3.2 software). HR-ESI-MS analysis was conducted using a Micromass Q-TOF micro instrument. Flash chromatography was carried out on a Grace Reveleris system equipped with dual UV and ELSD detection using Grace ${ }^{\circledR}$ cartridges (Silica gel or RP-C ${ }_{18}$ ). HPLC separations were performed on a Dionex apparatus equipped with an ASI-100 autosampler, an Ultimate 3000 pump, a STH 585 column oven, a diode array detector UVD 340 S and a Chromeleon software. A prepacked RP-C 18 column (Phenomenex 250 x $10 \mathrm{~mm}$, Luna $5 \mu$ ) was used for semi-preparative HPLC. The eluting mobile phase consisted of $\mathrm{H}_{2} \mathrm{O}$ with TFA $(0.0025 \%)$ and $\mathrm{CH}_{3} \mathrm{CN}$ with a flow rate of $5 \mathrm{~mL} / \mathrm{min}$ and the chromatogram was monitored at 205 and $210 \mathrm{~nm}$. Thin-layer chromatography (TLC) was carried out using silica gel $60 \mathrm{~F}_{254}$ pre-coated aluminium plates $(0.2 \mathrm{~mm}$, Merck). After developing with solvent systems, spots were visualized by spraying with $50 \% \mathrm{H}_{2} \mathrm{SO}_{4}$ followed by heating.

\subsection{Plant material}

The aerial parts of Salvia argentea L. var. aurasiaca (Pomel) Batt. \& Trab. were collected from Ain El-Bey, Constantine ( North-Eastern Algerian) in May 2014, and identified by professor Gérard de 
Bélair. A voucher specimen (LOST Saa.05/14) has been deposited at the herbarium of LOST Laboratory, University of Constantine, Algeria.

\subsection{Extraction and isolation}

The powdered dried aerial parts of S. argentea L. var. aurasiaca (950 g) were extracted with pure acetone by the use of a soxhlet extraction apparatus. The acetone solution was concentrated under reduced pressure to obtain the acetone extract (30 g). A part of this extract (15 g) was fractionated by column chromatography over silica gel eluted with a gradient of petroleum ether/acetone with increasing polarity (100:0-0:100, v/v), then methanol to yield 24 fractions (Frs A-X). Fraction L (748 mg) was separated by flash chromatography on RP-C ${ }_{18}$ column (40 g), eluted with gradient $\mathrm{MeOH}-\mathrm{H}_{2} \mathrm{O}(60 \%$ to $85 \% \mathrm{MeOH}$, in $28 \mathrm{~min})$ with flow rate of $40 \mathrm{~mL} / \mathrm{min}$ to afford compounds 2 (4 mg, yield: 0.027\%), 10 (25 mg, yield: 0.17\%) and 7 (10 mg, yield: 0.07\%). Fraction Q (600 mg) was subjected to flash chromatography on silica gel $(12 \mathrm{~g})$, eluted by a gradient system of petroleum ether/EtOAc (100:0 to 40:60, during $45 \mathrm{~min}$; flow rate, $36 \mathrm{~mL} / \mathrm{min}$ ), with $25 \mathrm{~mL}$ fractions collected and analyzed by TLC, fractions having similar compositions were combined to yield 29 fractions $\left(\mathrm{Q}_{1}-\mathrm{Q}_{29}\right)$. Fraction $\mathrm{Q}_{15}(34 \mathrm{mg})$ was purified by semi-prep HPLC using isocratic elution with $40 \%$ $\mathrm{CH}_{3} \mathrm{CN}$, in $25 \mathrm{~min}$ to give compound 5 (2 mg, yield: $\left.0.013 \%, t_{\mathrm{R}}=28.4 \mathrm{~min}\right)$. Fraction $\mathrm{Q}_{25}$ was obtained as pure compound 6 (61 mg, yield: 0.41\%). Fraction S (669 mg) was purified by flash chromatography on $\mathrm{RP}-\mathrm{C}_{18}$ column (40 g), eluted with $\mathrm{MeOH}-\mathrm{H}_{2} \mathrm{O}(50 \%$ to $80 \% \mathrm{MeOH}$, in 29 min; flow rate, $40 \mathrm{~mL} / \mathrm{min}$ ) to give twenty fractions based on TLC analysis, Frs $\mathrm{S}_{1-20}$. Compounds 8 (10 mg, yield: $0.07 \%$ ) and $\mathbf{1}\left(25 \mathrm{mg}\right.$, yield: $0.17 \%$ ) were obtained as pure compounds in fractions $\mathrm{S}_{7}$ and $\mathrm{S}_{11}$, respectively, while the fraction $\mathrm{S}_{14}(46 \mathrm{mg})$ was purified by semi-prep HPLC using a gradient of solvents $\mathrm{CH}_{3} \mathrm{CN}-\mathrm{H}_{2} \mathrm{O}\left(80 \%-100 \% \mathrm{CH}_{3} \mathrm{CN}, 20 \mathrm{~min}\right)$ to give compound 3 (3 mg, yield: $0.02 \%, t_{\mathrm{R}}$ $=11.0 \mathrm{~min})$. Fraction U (367 mg) was subjected to flash chromatography RP-C 18 column (40 g), eluted with $\mathrm{MeOH}-\mathrm{H}_{2} \mathrm{O}$ (40\%-100\% MeOH during $33 \mathrm{~min}$, with flow rate of $40 \mathrm{~mL} / \mathrm{min}$ ) with 25 $\mathrm{mL}$ fractions collected, based on TLC analysis were combined to give 20 fractions $\mathrm{U}_{1-20}$. The 
purification of fraction $\mathrm{U}_{20}(58 \mathrm{mg})$ by semi-prep HPLC using isocratic elution with $40 \% \mathrm{CH}_{3} \mathrm{CN}$ in $15 \mathrm{~min}$, afford compounds 9 (3 mg, yield: $\left.0.02 \%, t_{\mathrm{R}}=6.54 \mathrm{~min}\right)$ and 4 (6 mg, yield: $0.04 \%, t_{\mathrm{R}}=8.4$ $\min$ ).

For the extraction and purification of the exudate, fresh aerial parts $(4.5 \mathrm{~kg})$ were immersed in a mixture of toluene and EtOAc $(6: 4 v / v)$ for $20 \mathrm{~s}$ to yield the exudate crude extract $43 \mathrm{~g}$ which was previously fractionated and purified by Lakhal et al. (2014) to yield compounds 8, 9, and 11- 19.

3.4. $1 \beta, 3 \beta, 15 \alpha$-trihydroxy-urs-9(11)-12-diene (1)

Amorphous white powder; $\mathrm{C}_{30} \mathrm{H}_{48} \mathrm{O}_{3} ;[\alpha]_{D}^{25}+95.1\left(c 0.91, \mathrm{CHCl}_{3}\right) ;{ }^{1} \mathrm{H} \mathrm{NMR}\left(500 \mathrm{MHz}, \mathrm{CDCl}_{3}\right)$ and ${ }^{13} \mathrm{C}$ NMR $\left(125 \mathrm{MHz}, \mathrm{CDCl}_{3}\right)$ data, see Table 1; HR-ESI-MS m/z $457.3688[\mathrm{M}+\mathrm{H}]^{+}$(calcd 457.3682).

3.5. $1 \beta, 3 \beta, 15 \alpha, 28$-tetrahydrox-urs-9(11),12-diene (2)

Amorphous white powder; $\mathrm{C}_{30} \mathrm{H}_{48} \mathrm{O}_{4} ;[\alpha]_{D}^{25}+55.0\left(c 0.32, \mathrm{CHCl}_{3}\right) ;{ }^{1} \mathrm{H} \mathrm{NMR}\left(500 \mathrm{MHz}, \mathrm{CDCl}_{3}\right)$ and ${ }^{13} \mathrm{C}$ NMR $\left(125 \mathrm{MHz}, \mathrm{CDCl}_{3}\right)$ of spectroscopic data; see table 1. HR-ESI-MS $\mathrm{m} / \mathrm{z} 495.3457$ $[\mathrm{M}+\mathrm{Na}]^{+}($calcd 495.3450).

3.6. $1 \beta, 3 \beta$-dihydroxy-urs-9(11),12-dien-28-al (3)

Amorphous white powder; $\mathrm{C}_{30} \mathrm{H}_{46} \mathrm{O}_{3} ;[\alpha]_{D}^{25}+49.0\left(c\right.$ 0.21, $\left.\mathrm{CHCl}_{3}\right) ;{ }^{1} \mathrm{H} \mathrm{NMR}\left(500 \mathrm{MHz}, \mathrm{CDCl}_{3}\right)$ and ${ }^{13} \mathrm{C}$ NMR $\left(125 \mathrm{MHz}, \mathrm{CDCl}_{3}\right)$ data, see Table 1; HR-ESI-MS $\mathrm{m} / z 477.3349[\mathrm{M}+\mathrm{Na}]^{+}$(calcd 477.3345).

3.7. $1 \beta, 3 \beta, 7 \beta, 15 \alpha, 28$-pentahydroxy-urs-12-ene (4)

Amorphous white powder; $\mathrm{C}_{30} \mathrm{H}_{50} \mathrm{O}_{5} ;[\alpha]_{D}^{25}+19.4$ (c 0.52, MeOH); ${ }^{1} \mathrm{H}$ NMR $\left(500 \mathrm{MHz}, \mathrm{CD}_{3} \mathrm{OD}\right)$ and ${ }^{13} \mathrm{C}$ NMR (125 MHz, CD ${ }_{3} \mathrm{OD}$ ) data, see Table 1; HR-ESI-MS $m / z$. $513.3564[\mathrm{M}+\mathrm{Na}]^{+}$(calcd 513.3556). 
3.8. $1 \beta, 3 \beta, 15 \alpha$-trihydroxy-urs- 12 -ene- 28 -al (5)

Amorphous white powder; $\mathrm{C}_{30} \mathrm{H}_{48} \mathrm{O}_{4} ;[\alpha]_{D}^{25}+1.1$ (c 0.19, MeOH); ${ }^{1} \mathrm{H}$ NMR $\left(500 \mathrm{MHz}, \mathrm{CD}_{3} \mathrm{OD}\right)$ and ${ }^{13} \mathrm{C}$ NMR (125 MHz, CD $\left.{ }_{3} \mathrm{OD}\right)$ data, see Table 1; HR-ESI-MS $m / z 495.3445[\mathrm{M}+\mathrm{Na}]^{+}$(calcd 495.3450).

\section{Antibacterial Activity.}

The antibacterial screening was performed on five bacteria obtained from the Laboratory of Microbiology, faculty of pharmacy from the University of Reims Champagne-Ardenne including the following Gram-positive bacteria: Enterococcus faecalis ATCC 1034, Staphylococcus aureus CIP 53.154, and Staphylococcus epidermidis, and the Gram-negative bacteria Escherichia coli CIP 54.127 and Pseudomonas aeruginosa ATCC 9027. The five bacteria were incubated overnight at 37 ${ }^{\circ} \mathrm{C}$ in tubes containing Mueller-Hinton (MH) broth medium. The bacteria were then diluted with MH-broth by means of serial dilution to finally reach a concentration of $10^{5}$ bacteria/mL.

To identify the most promising compounds in terms of antibacterial activity, an immersion bioautography method was adopted [11]. Compounds 1-19 were solubilized in methanol to obtain a solution of $2 \mathrm{mg} / \mathrm{mL}$ and $25 \mu \mathrm{L}$ of each solution was spotted onto Merck $60 \mathrm{~F}_{254}$ pre-coated silica gel plates $(10 \times 10 \mathrm{~cm})$. Methanol and Gentamicin $(50 \mu \mathrm{g})$ were also spotted on the plates as negative and positive controls, respectively. The TLC plates were directly dried without migration and sterilized. The plates were then covered by Mueller-Hinton (MH) agar medium containing a Staphylococcus aureus CIP 53.154 suspension $\left(10^{5}\right.$ bacteria/mL) in square Petri dishes. After incubation for $24 \mathrm{~h}$ at $37^{\circ} \mathrm{C}$, bacterial growth was revealed by a $2 \mathrm{mg} / \mathrm{mL}$ solution of thiazolyl blue tetrazolium bromide (MTT) and growth inhibition zones were measured. White stains indicated where reduction of MTT to the colored formazan did not take place due to the presence of extracts that inhibited bacterial growth.

A serial dilution technique using 96-well microliter plates was used to determine the MIC values of the most promising compounds as revealed by bioautography. For this purpose, nine concentrations of the most active compounds, from $500 \mu \mathrm{g} / \mathrm{mL}$ to $2 \mu \mathrm{g} / \mathrm{mL}$, were tested. Two wells were 
represented as bacteria culture control (positive control) and medium sterility control (negative control). Then the wells were loaded with $\mathrm{MH}$ liquid medium and bacterial suspension $\left(10^{5}\right.$ bacteria/mL) giving a final volume of $200 \mu \mathrm{L}$. The plates were incubated overnight at $37^{\circ} \mathrm{C}$, sprayed with a $0.2 \mathrm{mg} / \mathrm{mL}$ MTT solution and incubated again at $37^{\circ} \mathrm{C}$ for $30 \mathrm{~min}$. Bacterial growth was indicated by a violet color whatever the color intensity, while bacterial growth inhibition was admitted only for wells which remained clear. MIC values were determined as the lowest concentrations of samples having an inhibitory effect on bacteria growth (clear wells). Gentamicin and vancomycin were used as positive antibacterial controls. Solvents were checked for absence of antibacterial activity.

\section{Antiproliferative activity}

Chronic myeloid leukemia K562 cells were cultured in suspension in RPMI1640 culture medium, while fibrosarcoma HT1080 cells are adherent and were cultured in MEM culture medium. The culture medium was completed by $10 \%$ fetal bovine serum and $1 \%$ antibiotics. In order to determine the anticancer activity of the compounds, K562 and HT1080 cells were spread onto 96well flat-bottom plates at a density of 1000 cells per well, and then incubated for $24 \mathrm{~h}$ in RPMI 1640 Medium supplemented with $10 \%$ fetal bovine serum and antibiotics. Cells were then treated with compounds 1-19 for 72 h. Cell growth was analyzed using 3-(4,5-dimethylthiazol-2-yl)-5-(3carboxymethoxyphenyl)-2-(4-sulfophenyl)-2 $H$-tetrazolium inner salt (MTS) according to the manufacturer's instructions (Promega Corporation, Charbonnières, France). Doxorubicin was used as a positive control. MTS is bioreduced by cells into a colored formazan product. Absorbance was analyzed at a wavelength of $540 \mathrm{~nm}$ with a Multiskan Ex microplate absorbance reader (Thermo Scientific, Paris, France). Percentage of cell growth was calculated as $100 \% \times(($ absorbance of the treated cells) / (absorbance of the negative control cells)). Control cells were treated with complete culture medium containing $0.2 \%$ DMSO. The values represent averages of three independent experiments. 


\section{Supplementary data}

HR-ESI-MS spectra and 1D and 2D NMR of 1-5

\section{Acknowledgements.}

The authors are grateful to MESRS Algeria for the Profas grant to Ms Sara Bechkri, to CNRS,

Conseil Regional Champagne Ardenne, Conseil General de la Marne, Ministry of Higher Education, Research and Innovation (MESRI) in France and EU-programe FEDER to the PlAneT CPER project for financial support.

\section{References}

[1] P. Quezel, S. Santa, New flora of Algeria and the southern desert regions, CNRS, Paris, 1963.

[2] K.A. Beladjila, R.Cotugno, D. Berrehal, Z. Kabouche, N. De Tommasi, A. Braca, M. De Leo, Cytotoxic triterpene from Salvia buchananii roots, Nat. Prod. Res. 32 (2018) 2025-2030.

[3] B.M. Fraga, C.E. Diaz, A. Guadan, A. Gonzalez-Coloma, Diterpenes from Salvia broussonetti transformed roots and their insecticidal activity, J. Agric. Food Chem. 53 (2005) 5200-5206.

[4] D. Gorai, S.K. Jash, R. Roy, Ursan's of the genus Salvia, Indo. Am. J. Pharm. Res. 6 (2016) 4242-4253.

[5] A. Kabouche, N. Boutaghane, Z. Kabouche E. Seguin, F. Tillequin, K. Benlabed, Components and antibacterial activity of the roots of Salvia jaminiana, Fitoterapia. 76 (2003) 450-452.

[6] A. Kabouche, Z. Kabouche, M. Ozturk, U. Kolak, G.Topçu, Antioxidant abietane diterpenoids from Salvia barrelieri, Food Chem. 102 (2007) 1281-1287.

[7] A. Kabouche, Z. Kabouche, R. Touzani, C. Bruneau, Diterpenes and sterols from the roots of Salvia verbenaca susbsp. clandestina, Chem. Nat. Compds. 44 (2008) 824-825.

[8] A. Kabouche, Z. Kabouche, Bioactive diterpenoids of Salvia species, Stud. Nat. Prod. Chem. 35 (2008) 753-833. 
[9] S.K. Jash, D. Gorai, R. Roy, Salvia genus and triterpenoids, Int. J. Pharm. Sci. Res. 7(2016 ) 4710-4732.

[10] U. Kolak, A. Kabouche, M. Ozturk, Z. Kabouche, G. Topçu, A. Ulubelen, Antioxidant diterpenoids from the roots of Salvia barrelieri, Phytochem. Anal. 20 (2009) 320-327.

[11] M. Lehbili, A. Alabdul Magid, A. Kabouche, L. Voutquenne-Nazabadioko, A. Abedini, H. Morjani, S.C. Gangloff, Z. Kabouche, Antibacterial, antioxidant and cytotoxic activities of triterpenes and flavonoids from the aerial parts of Salvia barrelieri Etl, Nat. Prod. Res. 32(22) (2018) 2683-2691.

[12] Y.B. Wu, Z.Y. Ni, Q.W Shi, M. Dong, H. Kiyota, Y.C. Gu, B. Cong, Constituents from Salvia species and their biological activities, Chem. Rev. 112 (2012) 5967-6026.

[13] K.B. Salah, M.A. Mahjoub, S. Ammar, L. Michel, J. Millet-Clerc, J.P. Chaimont, Z. Mighri, M. Aouni, Antimicrobial and antioxidant activities of the methanolic extracts of three Salvia species from Tunisia, Nat. Prod. Res. 20 (2006) 1110-1120.

[14] A.R. Jassbi, S. Zare, O. Firuzi, J. Xiao, Bioactive phytochemicals from shoots and roots of Salvia species, Phytochem Rev. 15 (2015) 829-867.

[15] L. Riccobono, A. Maggio, S. Rosselli, V. Ilardi, F. Senatore, M. Bruno, Chemical composition of volatile and fixed oils from Salvia argentea L. (Lamiaceae) growing wild in Sicily, Nat. Prod. Res. 30 (2016) 25-34.

[16] Y. Benabdesslem, K. Hachem, K. Kahloula, M. Slimani, Ethnobotanical survey, preliminary physico-chemical and phytochemical screening of Salvia argentea (L.) used by herbalists of the Saïda province in Algeria, Plants. 6 (2017) 59.

[17] H. Lakhal, A. Kabouche, A. Alabdul Magid, L. Voutquenne-Nazabadioko, D. Harakat, Z. Kabouche, Triterpenoids from Salvia argentea var. aurasiaca (Pomel) Batt. \& Trab. and their chemotaxonomic significance, Phytochemistry. 102 (2014) 145-151. 
[18] M. Gan, S. Lin, Y. Zhang, J. Zi, W. Song, J. Hu, N. Chen, L. Wang, X. Wang, J. Shi, Liposoluble constituents from Iodes cirrhosa and their neuroprotective and potassium channel-blocking activity, China Journal of Chinese materia medica. 36 (2011) 1183-1189.

[19] S. Matsunaga, R. Tanaka, M. Akagi, Triterpenoids from Euphorbia maculata, Phytochemistry. 27 (1988) 535-537.

[20] R. Tanaka, S. Matsunaga, Triterpene dienols and other constituents from the bark of Phyllanthus flexuosus, Phytochemistry. 27 (1988) 2213-2217.

[21] X.H. Li, J.T. Feng, Y.P. Shi, Triterpenoids from Saussurea ussuriensis, Can. J. Chem. 86 (2008) 281-284. 